\title{
KEBUTUHAN FASILITAS POKOK PANGKALAN PENDARATAN IKAN CISOLOK 10 TAHUN MENDATANG
}

\author{
Basic Facility Necessity of Cisolok Fish Landing Base for Next 10 Years \\ Oleh: \\ Ayang Armelita Rosalia ${ }^{1 *}$, A.B. Pane ${ }^{2}$, Iin Solihin ${ }^{2}$ \\ ${ }^{1}$ Mahasiswa Pascasarjana Program Studi Teknologi Perikanan Laut, FPIK-IPB \\ ${ }^{2}$ Staf Pengajar Program Studi Teknologi Perikanan Laut, FPIK-IPB \\ *Korespondensi: ayang_armelita@apps.ipb.ac.id
}

\begin{abstract}
ABSTRAK
Pangkalan Pendaratan Ikan Cisolok (PPIC) terletak di sebelah barat dari Pelabuhan Perikanan Nusantara Palabuhanratu (PPNPr). Aktifitas di PPIC cukup ramai, karena fasilitas di PPIC belum memadai, maka PPIC tidak dapat digunakan secara maksimal. Penelitian ini bertujuan untuk menentukan prediksi volume produksi ikan hasil tangkapan di daratkan, menentukan prediksi jumlah armada penangkapan ikan, mendapatkan besaran kebutuhan panjang dermaga dan luas kolam pelabuhan untuk saat ini dan kebutuhan 10 tahun ke depan di PPIC. Metode penelitian ini adalah studi kasus. Perhitungan kebutuhan dermaga dan luas kolam saat ini dan 10 tahun kedepan menggunakan data bulanan produksi hasil tangkapan, jumlah dan ukuran armada penangkapan ikan; data hasil pengukuran langsung yaitu panjang dermaga, luas kolam, panjang kapal dan draft maksimum kapal yang paling besar, data hasil pengamatan langsung; yaitu kondisi fasilitas dermaga dan kolam pelabuhan. Hasil penelitian menunjukkan bahwa prediksi volume produksi ikan hasil tangkapan di PPIC pada tahun 2018 sebesar 1.188,603 ton, dan mencapai 5.426,818 ton pada tahun 2027. Prediksi jumlah armada penangkapan ikan pada tahun 2018 sebanyak 280 unit, dan mencapai 357 unit pada tahun 2027. Prediksi penambahan panjang dermaga yang dibutuhkan yaitu sebesar 742 $\mathrm{m}$, juga diperlukan penambahan luas kolam pelabuhan menjadi $72.254 \mathrm{~m}^{2}$ dan kolam -2,6 m.
\end{abstract}

Kata kunci: Fasilitas pokok pelabuhan, pelabuhan perikanan, pengembangan pelabuhan, PPI Cisolok.

\begin{abstract}
Cisolok Fish Landing Base (CFLB) located at west of Teritorial Fishing Port of Palabuhanratu (TFPPr). The activity in CFLB quite crowded, because of inadequate facilities at CFLB, the CFLB can not be used optimally. This study were aimed to determine the volume of the catch, prediction the number of fishing boats, and to get the amount of long docks and pool port area needed for the current and next 10 years in CFLB. This research method was case study. Calculation of the dock and pool area which needed for present and in the next 10 years used monthly data production of the catch, the number and size of the vessel. Data of direct measurement results were length of dock, pool area, length of vessel and the maximum draft of vessels. Data of direct observations were; condition of the dock facilities and pool of port. The results showed that the prediction volume of the catch in the CFLB for 2018 as many as 1188.6 tons, and reached 5426.8 tons in 2027. Prediction the number of vessel fleet in 2018 as many as 280 units, and reached 357 units in 2027. Additional prediciton the long of dock are $742 \mathrm{~m}$, also required the addition of the pool port area are $72254 \mathrm{~m}^{2}$ and the depth of the pool are $-2.6 \mathrm{~m}$.
\end{abstract}

Keywords: basic port facilities, fishing ports, port development, PPI Cisolok. 


\section{PENDAHULUAN}

Pelabuhan perikanan merupakan pusat aktivitas perekonomian suatu kawasan perikanan, sehingga keberadaannya sangat diperlukan dalam pembangunan perikanan tangkap. Pelabuhan perikanan mempunyai fungsi antara lain; untuk meningkatkan kelancaran operasi penangkapan ikan, pendaratan hasil tangkapan, pengolahan ikan dan pemasarannya. Sebagaimana disebutkan oleh Lubis (2012), pelabuhan perikanan merupakan tempat yang sangat penting dalam pengembangan industri perikanan, dan menjadi pusat pengembangan ekonomi perikanan, ditinjau dari aspek produksi, pengolahan dan pendistribusian.

Menurut (Lubis 1999 vide Lubis 2011), sebagian besar pelabuhan perikanan di Indonesia (70\%) masih belum berfungsi optimal dan belum dilengkapi dengan fasilitas yang memadai dan modern. Tidak semua pelabuhan perikanan memiliki fasilitas yang dibutuhkan, dan umumnya memiliki kondisi fasilitas yang sangat terbatas. Kondisi ketersediaan dan jumlah fasilitas pelabuhan perikanan yang belum memadai, merupakan salah satu faktor yang menghambat aktivitas pelabuhan perikanan di Indonesia. Perlu upaya yang besar untuk membenahi pelabuhan perikanan tersebut. Jika pelabuhan perikanan dikelola dengan baik dari segi fasilitas dan aktivitas, maka akan memajukan ekonomi di suatu wilayah, meningkatkan kesejahteraan masyarakat dan pendapatan asli daerah sehingga pelabuhan perikanan di Indonesia perlu untuk dikembangkan.

Pangkalan Pendaratan Ikan Cisolok (PPIC) merupakan salah satu tempat pendaratan ikan di Kecamatan Cisolok, Kabupaten Sukabumi. Hasil pengamatan awal memperlihatkan aktifitas di PPIC cukup ramai, tetapi karena fasilitas di PPIC belum memadai, maka PPI tidak dapat digunakan secara maksimal, yaitu dermaga dan kolam pelabuhan yang ada sudah tidak layak oleh karena itu nelayan harus mendaratkan ikan ke pinggir pantai dan sekaligus sebagai tempat pengisian bahan kebutuhan melaut. Lokasi pendaratan Hasil Tangkapan (HT) dengan Tempat Pelelangan Ikan (TPI) yang ada adalah cukup jauh, sehingga nelayan di sekitar wilayah pesisir Cisolok mengharapkan kemudahan pendaratan HT, pemuatan bahan kebutuhan melaut, penanganan, dan pemasaran hasil tangkapannya.

Keterbatasan fasilitas yang tersedia di PPIC di atas jelas menghambat aktivitas di PPIC. Kondisi fasilitas pokok kolam dan dermaga yang jauh dari optimal, sehingga diperlukan pengembangan fasilitas pokok yang ada. Menurut Mulyana (2011), banyaknya aktivitas akan menentukan berapa besar fasilitas yang dibutuhkan agar aktivitas di pelabuhan berjalan baik dan lancar. Penelitian ini bertujuan untuk menentukan prediksi volume produksi ikan hasil tangkapan di daratkan; menentukan prediksi jumlah armada penangkapan ikan; mendapatkan besaran kebutuhan panjang dermaga dan luas kolam pelabuhan untuk saat ini dan 10 tahun ke depan di PPIC.

\section{METODE PENELITIAN}

Penelitian lapang dilaksanakan pada bulan Agustus-Oktober 2017 di PPIC Kabupaten Sukabumi, Provinsi Jawa Barat. Metode yang digunakan adalah studi kasus terhadap permasalahan fasilitas-aktivitas kepelabuhanan perikanan di PPIC. Aspek yang diteliti dalam penelitian ini adalah kebutuhan dermaga dan kolam pelabuhan saat ini dan 10 tahun ke depan.

Pengumpulan data dan informasi meliputi pengumpulan data sekunder, pengamatan, pengukuran dan wawancara. Data sekunder yang digunakan adalah data time series bulanan volume produksi ikan hasil tangkapan di daratkan, data tahunan armada penangkapan ikan yang diperoleh dari Dinas Kelautan dan Perikanan (DKP) Sukabumi dan pustaka pendukung. Pengamatan secara langsung di lapangan terkait keadaan fasilitas dermaga, kolam pelabuhan. Pengukuran langsung yaitu data ukuran panjang kapal, panjang dermaga, luas kolam dan kedalaman kolam. Data wawancara yaitu kondisi dermaga, kolam pelabuhan, draft maksimum kapal yang paling besar, jarak antar kapal saat bertambat di pelabuhan, ukuran kapal. Penentuan responden pelaku pelabuhan adalah purposive 
sampling. Responden yang dipilih berjumlah 15 orang terdiri dari; 6 orang pengelola pelabuhan dan DKP Sukabumi, 5 orang nelayan PMT, 4 orang pedagang ikan.

Perhitungan panjang dermaga dilakukan berdasarkan data volume produksi ikan hasil tangkapan yang didaratkan di PPIC dalam setahun (VPT), LOA kapal terpanjang (L), jarak antara 2 kapal penangkapan ikan (s), jarak haluan/buritan kapal ke ujung dermaga (j), rata-rata volume produksi hasil tangkapan yang di daratkan per pendaratan (VPU), banyak hari pendaratan riil hasil tangkapan per tahun setiap kapal (HPR), banyak frekuensi periode penggunaan dermaga per hari di pelabuhan perikanan (FP).

Perhitungan panjang dermaga pendaratan hasil tangkapan menggunakan rumus Pane 2016:

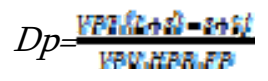

Perhitungan luas kolam (L) berdasarkan data luas kolam untuk memutar kapal (Lt), jumlah kapal maksimum yang berlabuh (n), panjang kapal rata-rata (l), lebar kapal rata-rata $\pi=3,14$ dan konstanta $=3$. Perhitungan $(\mathrm{Lt})$ dapat dilakukan dengan menggunakan rumus:

$$
\text { Lt=3,14 x ukuran kapal terpanjang }
$$

Penentuan kebutuhan luas kolam pelabuhan dilakukan dengan menggunakan rumus yang dipakai oleh Direktorat Jendral Perikanan sebagai berikut (Inconeb 1981 vide Syahputra 2015)

$$
L=L t+(3 \times n n x 1 \times b)
$$

Perhitungan kedalaman kolam (D) berdasarkan data draft kapal terbesar dengan muatan penuh (d), pasang surut kolam pelabuhan $(\mathrm{H})$, tinggi anggukan kapal yang melaju (S), jarak aman dari lunas kapal ke dasar perairan (C).

Penentuan kedalaman kolam pelabuhan dilakukan dengan menggunakan rumus yang dipakai oleh Direktorat Jendral Perikanan sebagai berikut (Inconeb 1981 vide Syahputra 2015).

$$
D=d+H+S+C
$$

Perhitungan kebutuhan panjang dermaga, luas dan kedalaman kolam pelabuhan untuk 10 tahun ke depan mengacu pada rumus-rumus di atas. Prediksi produksi ikan hasil tangkapan dan armada penangkapan ikan selama 10 tahun ke depan menggunakan analisis dan regresi (Dajan 1973 vide Pane 2013) dan model persamaan multiplikatif.

Secara umum persamaan regresi dapat dituliskan sebagai berikut:

$$
\hat{Y}=a+b X
$$

Keterangan:

a : Konstanta

$b \quad$ : Konstanta koefisien regresi

$Y \quad$ : Prediksi produksi ikan hasil tangkapan didaratkan

$X \quad$ : Waktu (bulan,tahun)

$$
\begin{gathered}
b=\frac{n x^{2} x-4 x x}{n 2 x^{7}-2 x^{4}} \\
a=c-b \bar{X}
\end{gathered}
$$

Keterangan :

$c \quad=$ rata - rata volume produksi hasil tangkapan didaratkan (ton)

$\bar{X} \quad=$ rata - rata waktu (bulan, tahun) 
Koefesien korelasi Pearson $\bigvee_{x x}$ bltung menggunakan rumus sebagai berikut:

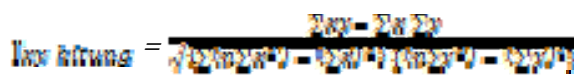

Hipotesis :

Ho $: r_{x y}=0 \longrightarrow$ tidak ada korelasi antara variabel $\mathrm{x}$ volume produksi hasil tangkapan dan variabel y waktu (bulan, tahun)

Ho $: r_{x y} \neq 0 \longrightarrow$ ada korelasi antara variabel $\mathrm{x}$ dan variabel $\mathrm{y}$

Keputusan :

Jika $\operatorname{liw}_{\text {bltung }}<=\mathrm{r}$ tab $\longrightarrow$ terima Ho : tidak ada korelasi antara variabel $\mathrm{x}$ dan variabel $\mathrm{y}$

Jika la $_{\text {a }}$ bltung $>=\mathrm{r}$ tab $\longrightarrow$ terima Ho : ada korelasi antara variabel $\mathrm{x}$ dan variabel $\mathrm{y}$

Perhitungan error menggunakan rumus tandard Error Estimated (SEE):

$$
S E E=\sqrt{\frac{R_{i}}{n}}
$$

Keterangan:

$e=$ error; $n=$ banyak pengamatan (indeks waktu bulan $\mathrm{i} ; 1=1,2,3, \ldots, \mathrm{n}$ )

Metode prediksi menggunakan model multiplikatif (Dajan 1973, Makridakis 1998, Sudjana 1973), model persamaannya adalah:

$$
\hat{Y} i=T s i x \operatorname{Six} C i
$$

Keterangan:

$\hat{Y} i \quad=$ Prediksi volume produksi ikan hasil tangkapan didaratkan bulanan pada periode bulan ke-i

Tsi = Pengaruh komponen trend seasonal terhadap volume produksi ikan hasil tangkapan didaratkan pada periode bulan ke-i

Si = Pengaruh komponen variasi musim (seasonal variation) terhadap volume produksi ikan hasil tangkapan didaratkan pada periode bulan ke-i

$C i \quad=$ Pengaruh komponen variasi siklik (cyclical variation) terhadap volume produksi ikan hasil tangkapan didaratkan pada periode bulan ke-i

$E i \quad=$ Pengaruh error yang timbul pada periode bulan ke-i

$i \quad=$ Indeks waktu bulan $1,2,3, \ldots . ., \mathrm{n}$

Langkah-langkah untuk penyelesaian model multiplikatif adalah sebagai berikut:

1. Dari data aktual $Y i$, ditentukan rata-rata bergerak (moving average) 11 bulan dengan menggunakan data sekunder selama 10 tahun terakhir. Tujuan dari tahap ini adalah untuk mengetahui nantinya pengaruh Trend ( $T S I)$ dan pengaruh siklik $(C I)$ :

$$
M i=T s i x C i \longrightarrow T s i=M i / C i ; C i=M i / T s i
$$

2. Menentukan pengaruh musiman ( $I i)$ dilakukan pembagian:

$$
S i=(Y i / M i) / E i
$$

3. Untuk memperoleh komponen siklik $(C 1)$, maka dilakukan pembagian:

$$
\mathrm{Ci}=\mathrm{Mi} / \mathrm{Tsi}
$$

4. Untuk keperluan prediksi, digunakan ketiga komponen ( $T$ si,Ii, $C I$ ) sebagai berikut:

$$
\hat{Y} i=T \text { si } x \text { Si } x \text { Ci, atau }
$$

5. Untuk keperluan pengembangan, sebagai berikut:

$$
\hat{Y} i=(T s i x \text { Si } x \text { Ci })+F P i
$$


Model persamaan prediksi ditentukan pada saat rata-rata bergerak $\mathrm{RB}=11$ bulan oleh error (SEE) yang terkecil dan koefisien korelasi $\mathrm{r}$ terbesar. Untuk memperkecil error dan memperbesar koefisien korelasi dilakukan pembersihan data ekstrim, data nol, dan penghalusan data menggunakan rata-rata bergerak (moving average) diatas terhadap data pengamatan. Data yang digunakan menggunakan data volume produksi hasil tangkapan bulanan di daratkan tahun 2010-2016. Dilakukan penghitungan pengaruh trend, variasi musim dan variasi siklik sebelum melakukan prediksi. Prediksi volume produksi hasil tangkapan telah memasukkan rancangan pengembangan armada penangkapan ikan yang diinginkan pihak pengelola PPI Cisolok dan Dinas Kelautan dan Perikanan (DKP) Kabupaten Sukabumi.

\section{HASIL DAN PEMBAHASAN}

\section{Prediksi Jumlah Armada Penangkapan Ikan di PPIC 2018-2027}

Perkembangan jumlah armada penangkapan ikan Perahu Motor Tempel (PMT) selama periode tahun 2012-2016 disajikan pada Gambar 1.

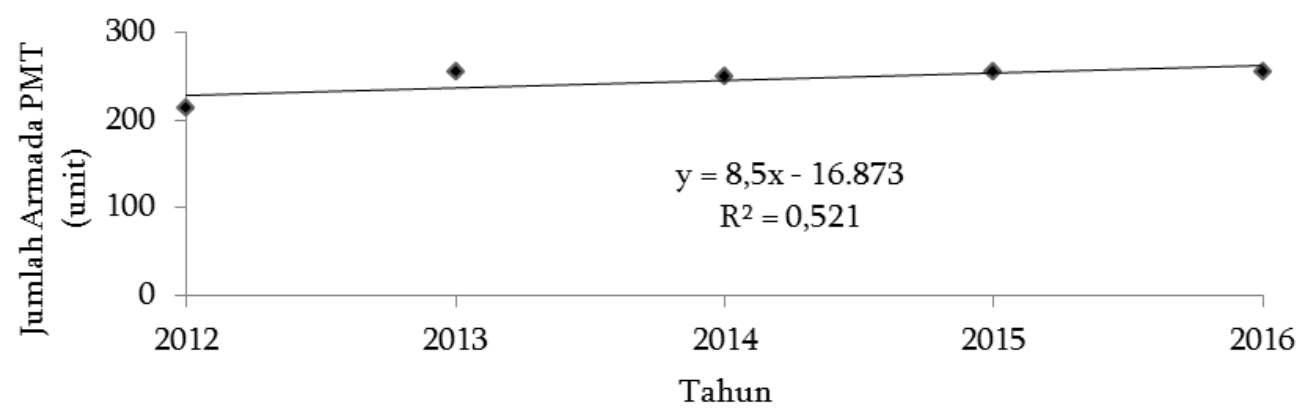

Sumber: Data DKP Sukabumi 2017, diolah kembali

Gambar 1 Grafik perkembangan dan persamaan Trend jumlah armada penangkapan ikan 2012-2016

Gambar 1 menunjukkan bahwa perhitungan persamaan regresi armada penangkapan ikan menghasilkan persamaan $\hat{y}=8,5 x-16.873$ ( $\hat{y}=$ armada penangkapan ikan per unit $\mathrm{x}=$ tahun). Persamaan regresi tersebut menggambarkan bahwa setiap penambahan $\mathrm{x}=1$ tahun maka akan meningkatkan jumlah armada penangkapan ikan sebesar $\hat{y}=8,5$ unit. Hubungan antar variabel armada penangkapan ikan $(\hat{y})$ unit dan waktu $(\mathrm{x})$ tahun adalah kuat; yang dinyatakan dengan $\mathrm{r}=0,7218$. Perkembangan jumlah armada perahu penangkap ikan 2012-2016 memiliki trend yang relatif meningkat; dengan asumsi stok sumber daya ikan yang ada di daerah-daerah penangkapan ikan mencukupi.

Prediksi jumlah armada penangkapan ikan PMT di PPIC untuk kurun waktu tahun 2018-2027, menggunakan data tahunan armada penangkapan ikan di PPIC selama 5 tahun terakhir 2012-2016, dapat dilihat pada Tabel 1.

Prediksi peningkatan jumlah armada penangkapan ikan PMT di PPIC diduga terjadi pada setiap tahunnya; pada tahun 2016 berjumlah 256 unit menjadi 280 unit ditahun 2018, kemudian meningkat 5 tahun kemudian, 2022 menjadi 314 unit dan mencapai 357 unit pada tahun 2027. Menurut Lubis 2011, semakin besar pertambahan jumlah dan ukuran armada penangkapan di suatu pelabuhan perikanan, maka armada penangkapan tersebut membutuhkan penambahan ukuran dermaga dan kolam pelabuhan yang sesuai untuk bersandar. 
Tabel 1 Prediksi jumlah armada Perahu Motor Tempel (PMT) di PPIC tahun 2018-2027

\begin{tabular}{ccc}
\hline \multirow{2}{*}{ Tahun } & \multicolumn{2}{c}{$\begin{array}{c}\text { Prediksi jumlah armada penangkapan ikan } \\
\hat{y}=8,5 \mathrm{x}+16.873\end{array}$} \\
\cline { 2 - 3 } & (Unit) & Presentasi Peningkatan (\%) \\
\hline 2018 & 280 & - \\
2019 & 289 & 3,0 \\
2020 & 297 & 2,9 \\
2021 & 306 & 2,9 \\
2022 & 314 & 2,8 \\
2023 & 323 & 2,7 \\
2024 & 331 & 2,6 \\
2025 & 340 & 2,6 \\
2026 & 348 & 2,5 \\
2027 & 357 & 2,4 \\
\hline Rata-rata/tahun & 579 & 2,720 \\
\hline Std Dev & 25,735 & 0,203 \\
\hline Kisaran: & & \\
Minimal & 280 & 2,4 \\
Maksimal & 357 & 3,0 \\
\hline
\end{tabular}

\section{Prediksi Volume Produksi Ikan Didaratkan di PPIC Tahun 2018-2027}

Trend volume produksi ikan hasil tangkapan di daratkan di PPIC tahun 2010-2016 dengan pola linear disajikan pada Gambar 2.

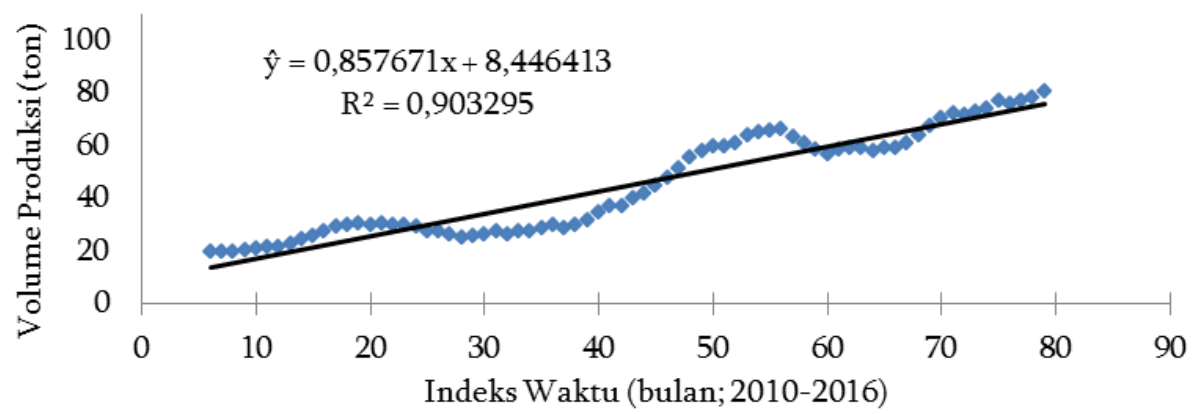

Sumber: Data DKP Sukabumi, 2017

Gambar 2 Grafik perkembangan dan persamaan Trend volume produksi ikan hasil tangkapan di daratkan di PPIC 2010-2016

Grafik perkembangan volume produksi ikan hasil tangkapan (Gambar 2), menunjukkan adanya fluktuasi volume produksi ikan hasil tangkapan setiap bulannya, akan tetapi secara keseluruhan perkembangan volume produksi ikan hasil tangkapan didaratkan di PPIC cenderung meningkat dari tahun 2010-2016.

Perhitungan persamaan regresi volume produksi hasil tangkapan, memberikan persamaan Trend regresi yaitu $\hat{y}=0,857671 \mathrm{x}+8,446413\{\hat{y}=$ volume produksi hasil tangkapan per bulan di PPIC tahun 2010-2016 (ton); $\mathrm{x}=\mathrm{i}=$ =Indeks waktu (bulan; 2010-2016=6,7,...,79)\} Persamaan regresi tersebut menggambarkan bahwa setiap penambahan $\mathrm{x}=1$ bulan maka akan meningkatkan produksi hasil tangkapan sebesar $\hat{y}=0,857671$ ton. Hubungan antar variabel produksi hasil tangkapan didaratkan $(\hat{y})$ ton dan indeks waktu (x) bulan adalah sangat kuat, yang dinyatakan dengan koefisien korelasi mendekati 1 yaitu r= 0,95, dengan nilai error SEE cukup baik 13,35\%. 
Hasil perhitungan perkalian persamaan trend, indeks musim, dan faktor siklik volume produksi ikan hasil tangkapan di daratkan di PPI Cisolok tahun 2010-2016 disajikan pada Tabel 2.

Tabel 2 Hasil perhitungan perkalian persamaan trend, indeks musim, dan faktor siklik volume produksi ikan hasil tangkapan di daratkan di PPIC tahun 2010-2016

\begin{tabular}{|c|c|c|c|c|c|c|}
\hline Tahun & $\begin{array}{l}\text { Indeks } \\
\text { waktu } \\
\text { (bulan; } \boldsymbol{x} \\
\text { atau 1) }\end{array}$ & $\begin{array}{l}\text { Persamaan } \\
\text { trend } \hat{Y} i \\
\quad \text { (ton) }\end{array}$ & $\begin{array}{l}\text { Variasi } \\
\text { musim } S i \\
\text { (indeks) }\end{array}$ & $\begin{array}{l}\text { Variasi } \\
\text { siklik } C i \\
\quad(\%)\end{array}$ & $\begin{array}{l}\text { Nilai prediksi } \\
\hat{Y}^{\prime} i=\hat{Y}_{i} x \operatorname{Ii}{ }_{x} C i \\
\text { (ton) }\end{array}$ & $\begin{array}{l}\text { Jumlah nilai } \\
\text { prediksi per } \\
\text { tahun } \sum \hat{Y} t \\
\text { (ton) }\end{array}$ \\
\hline $2010-2016$ & $1-84$ & - & - & - & - & - \\
\hline \multicolumn{2}{|c|}{ Rata-rata per bulan } & 44,90 & 100,0 & 102,7 & 46,2 & - \\
\hline \multicolumn{2}{|c|}{ Std Dev } & 20,92 & 9,57 & 2,6 & 22,3 & 273,82 \\
\hline \multirow{2}{*}{ Kisaran } & Min & 9,3 & 87,2 & 95,6 & 8,3 & 174,58 \\
\hline & Max & 80,5 & 114,9 & 105,8 & 93,1 & 935,10 \\
\hline
\end{tabular}

Tabel 2 menunjukkan bahwa pengaruh variasi musim terhadap nilai hasil prediksi volume produksi ikan hasil tangkapan didaratkan di PPI Cisolok tahun 2010-2016 adalah berada pada kisaran indeks 87,2-114,9. Nilai variasi musim yang berada diatas nilai rata-rata indeks musim perbulan (>100), terdapat pada bulan Februari, Juli, Agustus, September, Oktober, dan Desember, artinya pada bulan-bulan tersebut sedang terjadi musim-musim puncak pendaratan ikan hasil tangkapan di PPI Cisolok.

Rencana pengembangan/penambahan jumlah armada di PPI Cisolok tahun 2018-2027 disajikan pada Tabel 3.

Tabel 3 Rencana pengembangan/penambahan jumlah armada di PPIC tahun 2018-2027

\begin{tabular}{|c|c|c|c|c|c|c|c|}
\hline \multirow{2}{*}{ Tahun } & \multicolumn{2}{|c|}{ Jumlah KM (Unit) } & \multicolumn{2}{|c|}{$\begin{array}{l}\text { Rancangan Produktifitas } \\
\text { VP Ikan per Unit KM per } \\
\text { Tahun (ton/unit/tahun) }\end{array}$} & \multicolumn{3}{|c|}{$\begin{array}{c}\text { Rancangan Pengembangan VP Ikan per } \\
\text { Tahun (ton/tahun) }\end{array}$} \\
\hline & $\begin{array}{c}10 \mathrm{GT}<\mathrm{KM} \leq \\
20 \mathrm{GT}\end{array}$ & $\leq 10 \mathrm{GT}$ & $\begin{array}{c}10 \mathrm{GT}<\mathrm{KM} \leq \\
20 \mathrm{GT}\end{array}$ & $\leq 10 \mathrm{GT}$ & $\begin{array}{c}10 \mathrm{GT}<\mathrm{KM} \leq 20 \\
\mathrm{GT}\end{array}$ & $\leq 10 \mathrm{GT}$ & $\begin{array}{c}\text { Jumlah } \\
\text { Produksi } \\
(6+7)\end{array}$ \\
\hline (1) & (3) & (2) & (5) & (4) & (7) & (6) & (8) \\
\hline 2018 & - & - & - & - & - & - & - \\
\hline 2019 & - & - & - & - & - & - & - \\
\hline 2020 & - & 3 & - & 300 & - & 900 & 900 \\
\hline 2021 & - & 3 & - & 300 & - & 900 & 900 \\
\hline 2022 & - & 4 & - & 300 & - & 1.200 & 1.200 \\
\hline 2023 & 2 & 3 & 400 & 300 & 800 & 900 & 1.700 \\
\hline 2024 & 3 & 3 & 400 & 300 & 1.200 & 900 & 2.100 \\
\hline 2025 & 3 & 4 & 400 & 300 & 1.200 & 1.200 & 2.400 \\
\hline 2026 & 3 & 5 & 400 & 300 & 1.200 & 1.500 & 2.700 \\
\hline 2027 & 4 & 5 & 400 & 300 & 1.600 & 1.500 & 3.100 \\
\hline
\end{tabular}

Menurut Indrayani 2017, menyatakan bahwa PPI di Kabupaten Sukabumi perlu dilakukan pengembangan, dengan melihat belum tersedianya fasilitas dermaga dan kolam pelabuhan, maka perlu dilakukan pengembangan dermaga dan kolam pelabuhan agar perahu dapat melakukan aktivitasnya dengan baik.

Rencana pengembangan aktivitas di PPI Cisolok harus didukung dengan rencana pengembangan fasilitasnya, salah satunya adalah rencana pengembangan atau penambahan ukuran dan jumlah armada di PPI Cisolok untuk tahun 2018-2027. Tabel 3 menunjukkan rancangan 
pengembangan/penambahan ukuran dan jumlah armada dirancang oleh peneliti, berdasarkan keinginan pengembangan pihak pengelola PPI Cisolok, yang berdasarkan kepada rancangan produktivitas Volume Produksi (VP) ikan per unit kapal motor pertahun, dan yang mengacu kepada ukuran kapal motor yang sudah terdapat di Pelabuhan Perikanan Nusantara Palabuhanratu (PPNPr), serta ukuran kapal motor sesuai klasifikasi PPI yang terdapat di Permen KP No 08 tahun 2012 tentang Kepelabuhanan Perikanan yaitu sekurang-kurangnya 5 GT. Pengembangan armada penangkapan yang dilakukan adalah Kapal Motor (KM) ukuran $\leq 10 \mathrm{GT}$ dan $10 \mathrm{GT}<\mathrm{KM} \leq 20 \mathrm{GT}$. Rencana pengembangan ukuran dan jumlah armada dimulai pada tahun 2010, dengan jumlah 3 kapal motor, ukuran $\leq 10 \mathrm{GT}$, sampai dengan tahun 2027, dengan jumlah 5 kapal motor ukuran $\leq 10 \mathrm{GT}$, dan 4 kapal motor ukuran 10GT $<\mathrm{KM} \leq 20 \mathrm{GT}$. Rencana produktifitas VP ikan per unit KM, dimulai tahun 2020 sampai dengan tahun 2027 adalah 300 ton/unit untuk kapal motor $\leq 10 \mathrm{GT}$, dan 400 ton/unit untuk kapal motor $10 \mathrm{GT}<\mathrm{KM} \leq 20 \mathrm{GT}$. Dengan demikian, pertambahan jumlah volume produksi pengembangan sebagai akibat pengembangan armada penangkapan ikan ikan di PPI Cisolok mulai tahun 2020 adalah 900 ton, tahun 2024 adalah 2.100 ton, dan tahun 2027 adalah 3.100 ton.

Menurut Yuspardianto 2006, dalam meningkatkan kegiatan aktivitas Pelabuhan Perikanan dimasa akan datang diperlukan rencana pengembangan pelabuhan perikanan. Dengan tersedianya fasilitas yang memadai di Pelabuhan Perikanan, diharapkan dapat mendorong minat investor untuk menanamkan modalnya di Pelabuhan Perikanan tersebut.

Pengembangan terhadap fasilitas yang belum memadai perlu dilakukan, seperti perbaikan terhadap fasilitas yang rusak, penambahan kapasitas terhadap fasilitas yang belum memenuhi kebutuhan dan pembangunan fasilitas baru merupakan langkah nyata yang dapat dilakukan (Puspitasari 2013).

Hasil prediksi volume produksi ikan hasil tangkapan didaratkan di PPI Cisolok tahun 20182027 disajikan pada Tabel 4.

Tabel 4 Hasil prediksi volume produksi ikan hasil tangkapan didaratkan di PPIC tahun 2018-2027

\begin{tabular}{|c|c|c|c|c|c|c|c|}
\hline \multirow{3}{*}{ Tahun } & \multirow{3}{*}{$\begin{array}{c}\text { Indeks waktu } \\
\text { (bulan; } x \text { atau } \\
\text { i) }\end{array}$} & \multicolumn{3}{|c|}{ VP Bulanan } & \multirow{3}{*}{$\begin{array}{l}\text { VP per tahun } \\
\quad \text { (ton) }(\mathrm{A})\end{array}$} & \multirow{3}{*}{$\begin{array}{c}\text { VP } \\
\text { pengemban } \\
\text { gan (ton) } \\
\text { (B) }\end{array}$} & \multirow{3}{*}{$\begin{array}{l}\text { Jumlah VP } \\
\text { (ton) }(\mathrm{A}+\mathrm{B})\end{array}$} \\
\hline & & \multirow[b]{2}{*}{ Rata-rata } & \multicolumn{2}{|c|}{ Kisaran } & & & \\
\hline & & & Min & Max & & & \\
\hline 2018 & $97-108$ & 99,1 & 81,8 & 117,4 & $1.188,6$ & - & $1.188,6$ \\
\hline 2019 & $109-120$ & 109,6 & 91,0 & 129,6 & $1.315,4$ & - & $1.315,4$ \\
\hline 2020 & $121-132$ & 120,2 & 100,2 & 141,7 & $1.442,1$ & 900 & $2.342,1$ \\
\hline 2021 & $133-144$ & 130,7 & 109,4 & 153,9 & $1.568,9$ & 900 & $2.468,8$ \\
\hline 2022 & $145-156$ & 141,3 & 118,6 & 166,1 & $1.695,6$ & 1.200 & $2.895,6$ \\
\hline 2023 & $157-168$ & 151,9 & 127,7 & 178,3 & $1.822,4$ & 1.700 & $3.522,4$ \\
\hline 2024 & $169-180$ & 162,4 & 136,9 & 190,4 & $1.949,1$ & 2.100 & $4.049,1$ \\
\hline 2025 & $181-192$ & 172,9 & 146,2 & 202,6 & $2.075,9$ & 2.400 & $4.475,8$ \\
\hline 2026 & $193-204$ & 183,5 & 155,3 & 214,7 & $2.202,6$ & 2.700 & $4.902,6$ \\
\hline 2027 & $205-216$ & 194,0 & 164,5 & 227,0 & $2.326,8$ & 3.100 & $5.426,8$ \\
\hline \multicolumn{2}{|c|}{ Rata-rata/bulan } & 146,56 & - & - & 146,6 & - & - \\
\hline \multicolumn{2}{|c|}{ Std Dev } & 34,17 & 27,82 & 36,83 & 383,34 & 836,23 & $1.461,99$ \\
\hline \multirow{2}{*}{ Kisaran } & Min & 99,1 & 81,8 & 117,4 & $1.188,6$ & 900 & $1.188,6$ \\
\hline & Max & 193,9 & 164,5 & 226,9 & $2.326,8$ & 3.100 & $5.426,8$ \\
\hline
\end{tabular}

Tabel 4 menunjukkan bahwa prediksi volume produksi hasil tangkapan di atas menunjukkan adanya peningkatan volume produksi setiap tahunnya, dimana pada tahun 2018 volume produksi hasil tangkapan di PPIC menjadi sebesar 1.188,6 ton, tahun 2022 sebesar 2.895,6 dan meningkat hingga mencapai 5.426,8 ton pada tahun 2027. Prediksi hasil tangkapan 2018 sampai 2027 (Tabel 4) menghasilkan trend yang meningkat; dengan asumsi stok sumber daya ikan yang ada mencukupi, dan kondisi armada penangkapan ikan di lakukan pengembangan (ditambah jumlahnya). 
Berikut adalah grafik prediksi volume produksi ikan hasil tangkapan didaratkan di PPIC tahun 2018-2027 setelah dilakukan rancangan pengembangan (Gambar 3).

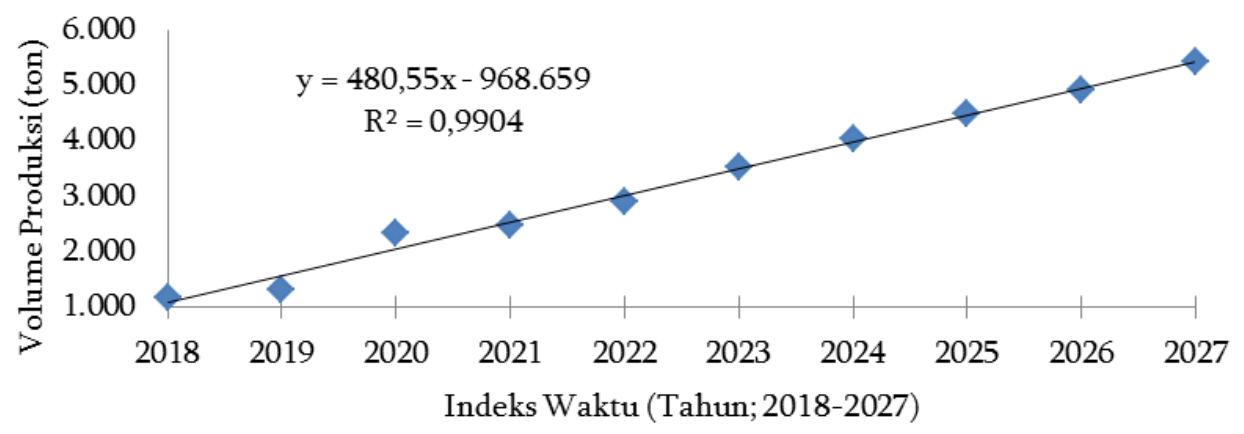

Gambar 3 Grafik hasil prediksi volume produksi ikan hasil tangkapan didaratkan dengan memperhitungkan pengaruh trend, variasi musim, dan variasi siklik di PPI Cisolok 2018-2027

(setelah dilakukan rancangan pengembangan)

Setelah dilakukan rancangan pengembangan maka persamaan prediksi volume produksi ikan hasil tangkapan didaratkan di PPI Cisolok tahun 2018-2027 menjadi Gambar 3, dengan persamaan regresi yaitu $\hat{y}=480,55 x-968659\{\hat{y}=$ Prediksi volume produksi hasil tangkapan per tahun di PPIC tahun 2018-2027 (ton); $\mathrm{x}=\mathrm{i}=$ Indeks waktu (tahun; 2018-2027)\}. Persamaan regresi tersebut menggambarkan bahwa setiap penambahan $\mathrm{x}=1$ tahun maka akan meningkatkan produksi hasil tangkapan sebesar $y=480,55$ ton. Hubungan antar variabel produksi hasil tangkapan didaratkan $(\hat{y})$ ton dan indeks waktu (x) bulan adalah sangat kuat, yang dinyatakan dengan koefisien korelasi mendekati 1 yaitu $\mathrm{r}=0,99$.

Prediksi volume produksi ikan hasil tangkapan di daratkan di PPI Cisolok akan terus mengalami peningkatannya 5\% sampai 10\% setiap tahunnya. Bila dibandingkan dengan pelabuhan perikanan sekelas yaitu PPI Kendonganan Kabupaten Badung Bali (Rini 2017), diperoleh bahwa hasil prediksi produksi hasil tangkapan didaratkan di PPIC relatif lebih rendang dibanding di PPI Kedonganan Kabupaten Bandung Bali yang mengalami peningkatan 12\% setiap tahunnya selama lima tahun mendatang. Dengan demikian secara teoritis produksi ikan hasil tangkapan PPI Cisolok pada periode tahun 2018-2027 bisa lebih ditingkatkan lagi.

\section{Kebutuhan Ukuran Panjang Dermaga Pendaratan PPIC Tahun 2018-2027}

Hasil perhitungan kebutuhan panjang dermaga saat ini dan 10 tahun kedepan diperoleh sebagai berikut (Tabel 5).

Tabel 5 Hasil perhitungan kebutuhan ukuran panjang dermaga PPIC 2018-2027

\begin{tabular}{lcc}
\hline Tahun & $\begin{array}{c}\text { Prediksi voume produksi } \\
\text { (ton) }\end{array}$ & $\begin{array}{c}\text { Panjang dermaga pendaratan } \\
(\mathrm{m})\end{array}$ \\
\hline 2017 (saat ini) & 955,8 & 473,5 \\
$2018^{*}$ & 1188,6 & 541,0 \\
$2022^{*}$ & 2895,6 & 660,4 \\
$2027^{*}$ & 5426,8 & 742,7 \\
\hline
\end{tabular}

Keterangan:

")Angka hasil prediksi, 2018 
Pada tahun 2017 PPIC hanya memiliki satu dermaga yaitu dengan panjang $240 \mathrm{~m}$, yang tidak digunakan karena kondisinya rusak dan adanya proses sedimentasi yang cukup besar. Hasil perhitungan (Tabel 5) menunjukkan bahwa perlunya penambahan fasilitas ukuran panjang dermaga saat ini (2017) dan 10 tahun kedepan. Berdasarkan perhitungan dibutuhkan panjang dermaga untuk tahun 2017 adalah 473,5 m, tahun 2018 adalah 541,0 m, tahun 2022 adalah 660,4 m, dan tahun 2027 dibutuhkan panjang dermaga 742,7 m. Pembangunan fasilitas dermaga dan penambahan ukuran panjang dermaga perlu dilakukan untuk meningkatkan aktivitas pendaratan hasil tangkapan ikan di PPIC 10 tahun kedepan.

Ukuran panjang dermaga di PPI Cisolok saat ini sudah cukup untuk skala PPI, bila dibandingkan panjang dermaga menurut Permen KP No 08 tahun 2012 tentang Kepelabuhan Perikanan dan di PPI Cituis. Menurut Permen KP tersebut, panjang dermaga PPI minimal $50 \mathrm{~m}$. Hasil penelitian Lubis (2011), menyatakan bahwa ukuran dermaga di PPI Cituis Tanggerang adalah 25,8 m, dan panjang dermaga PPI Cituis saat ini masih belum memenuhi standar kriteria, perlu adanya penambahan panjang dermaga sebesar 154,2 $\mathrm{m}$ atau panjang dermaga menjadi $180 \mathrm{~m}$.

\section{Kebutuhan Luas Kolam Pelabuhan PPIC 2018-2027}

Kebutuhan luas kolam pelabuhan di PPIC tahun 2018-2027 diperoleh sebagai berikut (Tabel 6).

Tabel 6 Hasil perhitungan kebutuhan luas kolam PPIC 2018-2027

\begin{tabular}{lccccc}
\hline Tahun & $\begin{array}{c}\text { Ukuran kapal } \\
\text { terpanjang } \\
(\mathrm{m})\end{array}$ & $\begin{array}{c}\text { Jumlah kapal } \\
\text { maksimum yang } \\
\text { berlabuh (unit) }\end{array}$ & $\begin{array}{c}\text { Panjang } \\
\text { kapal rata- } \\
\text { rata }(\mathrm{m})\end{array}$ & $\begin{array}{c}\text { lebar kapal } \\
\text { rata-rata } \\
(\mathrm{m})\end{array}$ & $\begin{array}{c}\text { Luas } \\
\text { kolam } \\
\left(\mathrm{m}^{2}\right)\end{array}$ \\
\hline 2017 (saat ini) & 12,5 & 256 & 11,0 & 2,6 & 22.004 \\
$2018^{*}$ & 12,5 & 280 & 11,0 & 2,6 & 24.063 \\
$2022^{\circ}$ & 14,0 & 314 & 13,0 & 3,0 & 36.782 \\
$2027^{\circ}$ & 20,0 & 357 & 15,0 & 4,5 & 72.254 \\
\hline
\end{tabular}

Keterangan:

")Angka hasil prediksi, 2018

Hasil perhitungan kebutuhan luas kolam PPIC 2017 (saat ini) dan 10 tahun kedepan menunjukkan bahwa perlunya penambahan ukuran fasilitas luas kolam pelabuhan. Saat ini kolam pelabuhan di PPIC tertutup oleh sedimen pasir, hal tersebut menyebabkan nelayan Cisolok tidak dapat mendaratkan ikan dengan aman, dan berdasarkan perhitungan tahun 2017 dibutuhkan kolam pelabuhan seluas $22.004 \mathrm{~m}^{2}$, prediksi tahun 2018 adalah $24.063 \mathrm{~m}^{2}$, tahun 2022 adalah $36.782 \mathrm{~m}^{2}$, dan pada tahun 2027 dibutuhkan kolam pelabuhan seluas $72.254 \mathrm{~m}^{2}$.

\section{Kebutuhan Kedalaman Kolam Pelabuhan 2018-2027}

Berikut adalah tabel hasil perhitungan kebutuhan kedalaman kolam di PPIC tahun 2018-2027 disajikan pada Tabel 7 .

Tabel 7 Hasil perhitungan kebutuhan kedalaman kolam PPIC 2018-2027

\begin{tabular}{lccc}
\hline \multirow{2}{*}{ Tahun } & $\begin{array}{c}\text { Draft kapal terbesar } \\
(\mathrm{m})\end{array}$ & $\begin{array}{c}\text { Tinggi anggukan kapal } \\
(\mathrm{m})\end{array}$ & Kedalaman kolam (m) \\
\hline 2017 (saat ini) & 0,5 & 0,1 & $-1,5$ \\
$2018^{\circ}$ & 0,5 & 0,1 & $-1,5$ \\
$2022^{\circ}$ & 1 & 0,2 & $-2,1$ \\
$2027^{\circ}$ & 1,5 & 0,2 & $-2,6$ \\
\hline
\end{tabular}

Keterangan:

"Angka hasil prediksi, 2018 
Hasil perhitungan kebutuhan kedalaman kolam PPIC 2017 (saat ini) dan 10 tahun kedepan menunjukkan bahwa perlu penambahan kedalaman kolam pelabuhan, dan berdasarkan tahun 2017 (saat ini) dan tahun 2018 dibutuhkan kedalaman kolam adalah 1,5 m, tahun 2022 adalah 2,1 m, dan pada tahun 2027 dibutuhkan kedalaman kolam pelabuhan adalah 2,6 m, merujuk pada rencana pengembangan/penambahan ukuran dan jumlah kapal motor, untuk mengantisipasi kebutuhan pelayanan kapal motor yang mendaratkan hasil tangkapan dan pemuatan bahan kebutuhan melaut di PPIC.

\section{KESIMPULAN DAN SARAN}

\section{Kesimpulan}

Perlu pengembangan ukuran fasilitas pokok PPI Cisolok. Prediksi jumlah volume produksi di PPIC meningkat mencapai 5.426,8 ton pada tahun 2027. Prediksi jumlah armada penangkapan ikan di PPIC terjadi peningkatan mencapai 357 unit pada tahun 2027. Prediksi penambahan ukuran dermaga dan kolam pelabuhan yang dibutuhkan untuk saat ini dan 10 tahun ke depan di PPIC yaitu sebesar $473 \mathrm{~m}$ untuk dermaga pada tahun 2017, dan tahun 2027 dibutuhkan panjang dermaga adalah $742 \mathrm{~m}$, juga perlunya penambahan luas kolam pada tahun 2017 dibutuhkan kolam pelabuhan seluas 22.004 m2 dan pada tahun 2027 dibutuhkan kolam pelabuhan seluas $72.254 \mathrm{~m} 2$.

Saran

Perlu pengembangan pelabuhan perikanan, pengerukan kolam pelabuhan dan perbaikan breakwater di PPI Cisolok.

\section{DAFTAR PUSTAKA}

Dajan A. 1973. Pengantar Metode Statistik Deskriptif. Jakarta: LP3ES. 452 hal.

Dinas Perikanan Kabupaten Sukabumi. 2011. Masterplan Minapolitan. Sukabumi (ID): Departemen Kelautan dan Perikanan.

Dinas Perikanan Kabupaten Sukabumi. 2017. Laporan Tahunan UPTD TPI. Sukabumi (ID): Departemen Kelautan dan Perikanan.

Indrayani L, Wibowo BA, Setiyanto I. 2017. Tingkat kondisi dan potensi pelabuhan perikanan di Kabupaten Sukabumi, Jawa Barat. Journal of Fisheries Resources Utilization Management and Technology. 6(4):352-364.

Lubis E. 2011. Kajian peran strategis pelabuhan perikanan terhadap pengembangan perikanan laut. Sumberdaya Perairan. 5(2): 1.1-7.

Lubis E, Mardiana N 2011. Peranan fasilitas PPI terhadap kelancaran aktivitas pendaratan ikan di Cituis Tanggerang. Teknologi Perikanan dan Kelautan. 1(2):1-8.

Lubis E. 2012. Pelabuhan Perikanan. Bogor (ID): IPB Press

Makridakis SG. Wheelwright SC, Hyndman RJ. 1998. Forecasting, Methods and Application. 3rd. New York (US): John Wiley \& Sons. 642 hal.

Mulyana R. Hubungan aktivitas pendaratan dan pelelangan terhadap kebutuhan fasilitas dan kondisi kualitas hasil tangkapan armada tradisional di PPS Nizam Zachman Jakarta [skripsi]. Bogor (ID): Institut Pertanian Bogor.

Pane AB. 2013. Latihan Statistik Reresi Korelasi Laboratorium Hasil Tangkapan dan Manajemen Industri Perikanan Divisi KPP: Departemen Pemanfaatan Sumberdaya Perikanan, Fakultas Perikanan dan Ilmu Kelautan, Institut Pertanian Bogor. 
Pane AB. 2016. Kajian pendaratan hasil tangkapan dan panjang dermaga di Pelabuhan Perikanan: rumus panjang dermaga adaptif bagi aktivitas Pelabuhan Perikanan. Laboratorium Hasil Tangkapan dan Manajemen Industri Perikanan Divisi KPP: Departemen Pemanfaatan Sumberdaya Perikanan, Fakultas Perikanan dan Ilmu Kelautan, Institut Pertanian Bogor.

Puspitasari N, Irnawati R, Susanto A. 2013. Strategi pengembangan pelabuhan perikanan nusantara karangantu kota serang provinsi banten. Ilmu Pertanian dan Perikanan. 2(2): 159-169.

Rini IPS, Bambang AN, Wibowo BA. 2017. Strategi pengembangan pangkalan pendaratan ikan (PPI) Kedonganan Kabupaten Bandung Bali. Journal of Fisheries Resources Utilization Management and Technology. 6(4):119-128.

Sudjana. 1973. Metode Statistik. Bandung: Tarsito.

Syahputra F. 2015. Analisis pengembangan fasilitas pokok Pelabuhan Perikanan Pantai (PPP) Lampulo Banda Aceh [Tesis]. Bogor(ID): Institut Pertanian Bogor.

Yuspardianto. 2006. Studi fasilitas pelabuhan perikanan dalam rangka pengembangan Pelabuhan Perikanan Samudera Bungus Sumatera Barat. Mangrove dan Pesisir. 6(1):47-56. 